Citation: Cruz-García, S., AguirreMedina, J. F., Espinosa-Zaragoza, S., Reyes-Reyes, J., Avendaño-Arrazate, C. H., Guzmán-Alfonzo, Y., \& AguirreCadena, J. F. (2021). Morphometric characteristics and seed germination of Dalbergia granadillo Pittier. Agro Productividad. https://doi.org/10.32854/ agrop.vl4il1.2156

Editor in Ghief: Dr. Jorge Cadena Iñiguez

Received: April 14, 2021. Accepted: Octubre 19, 2021. Published on-line: November 26, 2021

This work is licensed under a Creative Commons Attribution-NonCommercial 4.0 International license.

\section{Morphometric characteristics and seed germination of Dalbergia granadillo Pittier}

\author{
Cruz-García, Sergio $^{1^{*}}$; Aguirre-Medina, Juan Francisco ${ }^{2}$; Espinosa-Zaragoza, Saúl ${ }^{2}$; \\ Reyes-Reyes, Jorge ${ }^{2}$; Avendaño-Arrazate, Carlos Hugo ${ }^{2}$; Guzmán-Alfonzo, Yovani ${ }^{1}$; \\ Aguirre-Cadena, Juan F. ${ }^{2}$ \\ 1 Universidad Autónoma de Chiapas, Programa de Maestría en Ciencias en Producción Agropecuaria \\ Tropical. Carretera Ocozocuautla-Villaflores km. 84. Villaflores, Chiapas, México. G.P. 30476. \\ 2 Universidad Autónoma de Chiapas, Profesores-Investigadores de la Facultad de Ciencias Agrícolas. \\ Entronque Carretera Costera y Pueblo de Huehuetán, Chiapas, México. C.P. 30660. \\ * Correspondence: sercrugar.forest@gmail.com
}

\begin{abstract}
Objective: To know the variability and quality of seed in a Dalbergia granadillo Pittier (Fabaceae) population from the Soconusco, Chiapas, Mexico.

Design/methodology/approximation: The seed was obtained from six trees during the months of February and March 2020. Two weeks after the seeds were collected, pod and seed variables were determined. Seed length (LS), width (AS), color (CS), weight of 100 seeds (g) (PS) and germination percentage (PG). The results were statistically analysed by analysis of variance using the GLM procedure and the comparison of means by Tukey $(\mathrm{P} \leq 0.05)$ with the SAS 9.0 program.

Results: There is wide variation in seed content. The pods registered from 1, 2, 3 and up to four seeds, although pods of one predominated. There are seeds of two colours, dark brown and light brown, and the latter are the most abundant; however, light colored seeds registered higher germination (96\%). The weight of 100 seeds registered values of 9.6-9.7 g.

Study Limitations/implications: The species has a restricted distribution and presents a low number of individuals in the evaluated populations.

Findings/conclusions: The morphometric characteristics of the seeds allowed to identify the variability and quality, mainly in shape, size and coloration of the seeds, as well as the number of seeds per pod.
\end{abstract}

Key words: Granadillo, seed quality, weight, and germination.

\section{INTRODUCTION}

Tropical species considered as precious woods have been subjected to various anthropic actions, such as deforestation and fragmentation of their habitat. In addition to the above, it registers low natural repopulation, and they are of slow initial growth. The level of incidence of these factors or their combination, favor vulnerability to their loss (CITES, 2013; Cervantes, 2016). Dalbergia sp. (Fabaceae) is a tropical species, with a registered distribution in Chiapas, Guerrero, Jalisco, Michoacán, Nayarit and Oaxaca, (Pittier, 1922; CONABIO, 2017; CITES, 2015; Guala and Döring, 2020). The species D. granadillo Pittier known as granadillo (Pittier, 1922), cocobolo or rosewood (Cervantes, 2016) is considered high quality wood. Its contrasting colours, ranging from reddish-dark brown, with almost black veins of its heartwood and yellow sapwood, make it very attractive and increase its preference.

Its acoustic properties have been used since pre-Hispanic times by the Aztecs for the elaboration of musical instruments (Herrera-Castro et al., 2019), and currently in certain 
regions of Mexico (Suárez-Islas et al., 2020), it is used mainly to make studio and concert guitars (Guridi and García-López, 1996). It is also used to make handicrafts, kitchen utensils, castanets, marimba keys and decoration in general (Niembro, 1990).

It registers high natural durability when exposed in the soil compared to other tropical species (Colín-Urieta et al., 2019).

In the Soconusco, Chiapas, Mexico, the habitat destruction has been the action with the greatest impact over the $D$. granadillo (Díaz-Gallegos et al., 2010) populations, and at present it has been classified as an endangered species, both in NOM-059-SEMARNAT-(2010), as in the appendices of the Convention on International Trade of Species (CITES, 2016 a). An unquantified risk is that the immoderate logging of the habitat has caused the accelerated loss of its genetic diversity. This reduces the possibilities of generating knowledge about the germination process of its seed that facilitates the design of multiplication and reinsertion strategies. Based on the above, it was proposed to know the variability and quality of seed in a population of Dalbergia granadillo Pittier (Fabaceae) from the Soconusco, Chiapas, Mexico.

\section{MATERIALS AND METHODS}

\section{Location of the study area and biological material}

The trees from which the seeds were obtained are located in "La Rioja" Community, in Cacaohatán, Chiapas, Mexico (14 58' 37" LN and 92 $16^{\circ}$ ' 15" LO), at an altitude of $480 \mathrm{~m}$. The climate belongs to the warm humid group Af (w”) i g, with $4720 \mathrm{~mm}$ of annual precipitation and an average temperature of $25.4^{\circ} \mathrm{C}$ (INEGI, 2017). The soils have a volcanic origin and belong to the mollic Andosol group. They are characterized by the strong phosphate binding but are easy to grow and have good rooting and water storage characteristics (FAO, 2008). The soil of the place presents the following physicochemical characteristics: sand and loam texture $(82.5 \%$ sand, $12.3 \%$ silt, $5.2 \%$ clay, 3.7\% organic matter) (Walkley-Black), $0.12 \mathrm{ds} \mathrm{m}^{-1}$ electrical conductivity, pH 5.71, 0.13\% N (Kjeldhal), $4.0 \mathrm{ppm} \mathrm{P}$ (colorimetry), $18.5 \mathrm{ppm} \mathrm{K}^{++}$(atomic spectrophotometry), $59 \mathrm{ppm} \mathrm{Ca}^{++}$ (atomic spectrophotometry), $9.3 \mathrm{ppm} \mathrm{Mg}^{++}, 16.8 \mathrm{ppm} \mathrm{Na}^{++}$, y $5 \mathrm{Meq} 100 \mathrm{~g}^{-1}$ of cation exchange capacity.

\section{Collection date and number of trees}

Fruits were collected during February and March 2020 from six trees that constitute the population. Pods were collected from each tree and stored in labelled paper bags. The characterization was carried out in the Laboratory of Forest Biotechnology and Biofertilizers of the Faculty of Agricultural Sciences, Huehuetán, Chiapas (15 $19^{\prime} \mathrm{N}$ and $\left.92^{\circ} 44^{\prime} \mathrm{O}\right)$ where the pods with and without seeds were separated. The pods with seed were grouped according to the number of seeds and kept at room temperature in the laboratory $\left(23.2^{\circ} \mathrm{C}\right)$ in a ziploc ${ }^{\circledR}$ plastic bag.

At 15 days after its collection, basic initial quality tests were determined using the established rules of the International Seed Testing Association (ISTA, 2010), such as morphometric and germination variables (Table 1). 
Table 1. Variables of pods and seeds of D. granadillo Pittier collected in the Soconusco, Chiapas, Mexico.

\begin{tabular}{l|l}
\multicolumn{1}{c|}{ Variable } & \multicolumn{1}{c}{ Description } \\
\hline Number of pods per tree & The number of pods with seed of each tree was quantified. \\
\hline Pod length & $\begin{array}{l}\text { It was measured with a digital vernier (Caliper Brand, Stainless } \\
\text { Hardened, USA) with a precision of 0.1 mm. }\end{array}$ \\
\hline Seeds per pod & The number of seeds per pod in each tree was counted. \\
\hline Number and colour of seeds per tree & $\begin{array}{l}\text { The number of seeds per tree was recorded and separated for ger- } \\
\text { mination by colour; dark brown and light brown. }\end{array}$ \\
\hline Weight of 100 seeds & $\begin{array}{l}100 \text { seeds (g) were weighed with four repetitions on a digital scale } \\
\text { (Ohaus Brand, SocutPro Model SP401 USA). }\end{array}$ \\
\hline Number of seeds per kg & $\begin{array}{l}\text { It was determined by the formula (Number of seeds in the sample / } \\
\text { Weight of the sample) } * 100 . \text { ISTA, 2010). }\end{array}$ \\
\hline Germination & $\begin{array}{l}\text { It was measured in percentage (\%) according to the Testa colour } \\
\text { through the paper germination method (ISTA, 2010) the first ger- } \\
\text { mination count was made after } 5 \text { days and the last one on day 20. }\end{array}$ \\
\hline
\end{tabular}

\section{Statistical analysis}

The mean results of the variables in the induction phase were plotted with the Sigma Plot (V. 11.0) program from Jandel Scientific. The data of the variables in the multiplication stage were analysed with the SAS Program for Windows Ver. 8.1 (1999-2000) and the comparisons of means between treatments with Tukey $(\mathrm{P} \leq 0.05)$.

\section{RESULTS AND DISCUSSION}

\section{Number of pods and seeds per pod}

The trees show a difference in the number of pods and the number of seeds per pod. The values fluctuated between 65 to 102 pods among the trees and with 1, 2, 3 and up to 4 seeds (Table 2). The immature fruit has a green colour and resembles a leaf.

The number of pods with one seed dominated in all trees, and it appears to be a characteristic of the species. Tree 4, with the lowest number of pods, presented the highest percentage of pods with one seed, while trees 1, 2, 6 and 12, with the highest number of pods, represented on average $25 \%$ fewer pods with one seed. In trees 2, 6 and 12, the pods with two seeds fluctuated in percentage from 20 to $23 \%$ and only tree 1 registered $40 \%$. In the case of pods with three seeds in most trees, it represented between 3 and $7 \%$ of the total;

Table 2. Number of pods and seeds per pod of $D$. granadillo Pittier trees.

\begin{tabular}{c|c|c|r|r}
\hline \multirow{2}{*}{$\begin{array}{c}\text { Tree and total number } \\
\text { of pods }\end{array}$} & \multicolumn{4}{|c}{ Number of seeds per pod } \\
\cline { 2 - 5 } & $\mathbf{1}(\mathbf{\%})$ & $\mathbf{2}(\mathbf{\%})$ & $\mathbf{3}(\mathbf{\%})$ & $\mathbf{4}(\mathbf{\%})$ \\
\hline 1 (102 pods) & $56(54.9)$ & $40(39.3)$ & $5(4.9)$ & $1(0.98)$ \\
\hline 2 (84 pods) & $55(65.4)$ & $23(27.3)$ & $6(7.3)$ & \\
\hline 4 (65 pods) & $56(86.1)$ & $6(9.2)$ & $3(4.7)$ & \\
\hline 5 (78 pods) & $58(74.3)$ & $14(18.0)$ & $5(6.4)$ & $1(1.3)$ \\
\hline 6 (84 pods) & $49(58.4)$ & $20(23.8)$ & $15(17.8)$ & \\
\hline 12 (88 pods) & $60(68.2)$ & $20(22.7)$ & $7(7.9)$ & $1(1.2)$ \\
\hline
\end{tabular}


however, it increased to $15 \%$ in tree 6 . According to CITES, (2016) these data coincide with those found for Dalbergia calycina Benth.

\section{Seed length and width}

The size of the seeds was greater in three trees 1, 2 and 4 (Figure 1) and they do not present a relationship between the total number of pods and the percentages of seeds per pod. It is important to mention that the variation in the size of the seed plays a significant role in the germination process. This indicates that heavier seeds may be more appropriate for their multiplication (Seltmann et al., 2007).

The length and width values of the seeds did not coincide with the Dalbergia tucurensis Donn species, where the average value in the seeds was $1.0 \mathrm{~cm}$ long and $0.5 \mathrm{~cm}$ wide (CITES, 2016b). Changes in seed size also occur in accessions of various tropical forest species and the changes are contrasting, as in Cedrela odorata L. where Alderete-Chávez et al. (2005) cite differences in size based on length and width of the seeds with values of 2.60 $\mathrm{cm}$ and $3.64 \mathrm{~mm}$, respectively.

The size and weight of the seed are closely related to its reserve content, which varies between species. They are also related to the establishment, the growth of the seedlings and when the reserves are high, greater persistence of the species is achieved in a given site (Fenner and Thompson, 2005; Luna et al., 2018), it is also relevant to harvest the seed with optimal humidity to favour its benefit, conservation (Sánchez et al., 2010).

\section{Weight of 100 seeds}

The average weight of one hundred seeds per tree (W100S) was in a range of 8.8 and 9.2 $\mathrm{g}$, and the trees that expressed the highest values were 5 and 6 (Figure 2). The differences in the size of the seeds, which induce weight differences, occur in other tropical species, such as Cedrela odorata L. (Arce-Córdoba et al., 2018).

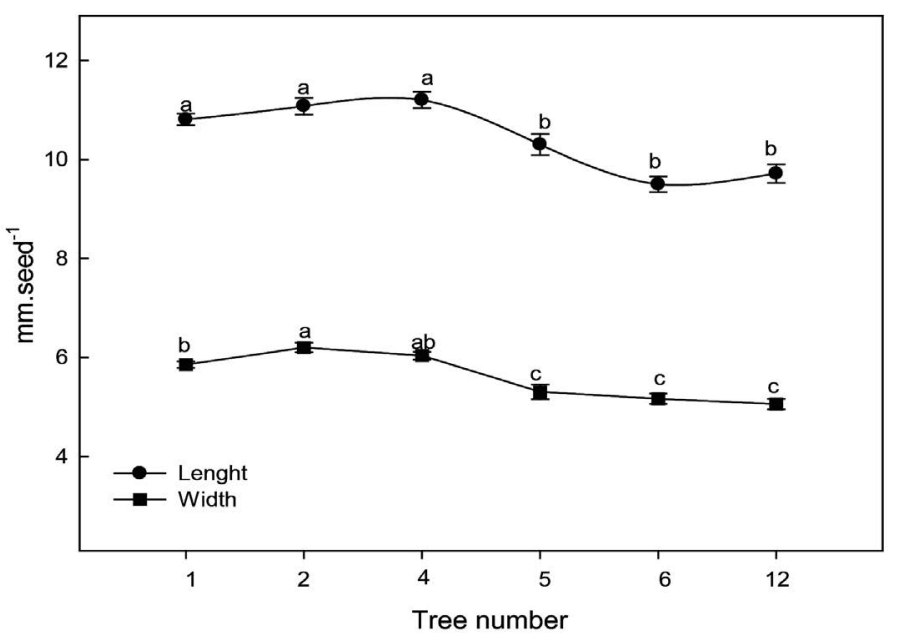

Figure 1. Length and width of D. granadillo Pittier seeds from six trees located in Soconusco Chiapas, Mexico. The values are means of 35 repetitions \pm standard error and the letters that are not equal indicate statistical difference (Tukey $\mathrm{p} \leq 0.05)$. 


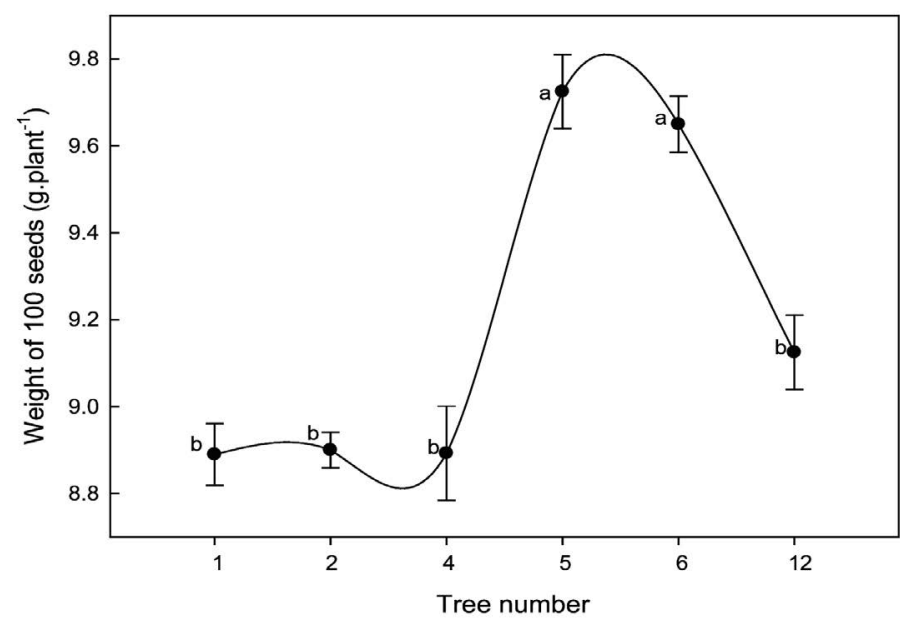

Figure 2. Weight of 100 seeds per tree of D. granadillo collected in the Soconusco region, Chiapas Mexico. The values are means of 35 repetitions \pm standard error and the letters that are not equal indicate statistical difference (Tukey $\mathrm{p} \leq 0.05)$. $\mathrm{CV}=1.7 \%$.

The variation in the weight of 100 seeds can be influenced by genetic factors in interaction with the environment, and in this regard, Mendizábal-Hernández et al. (2012; 2013) mention that the differences may also be due to pollen viability and fertility, as well as stigmatic receptivity.

In other species, such as C. odorata L., Arce-Córdova et al. (2018) and Roseodendron donnell-smithii Miranda, Agustín-Sandoval et al. (2017) variations in weight of 100 seeds between collections in the same region of Soconusco, Chiapas are consigned. It is important to highlight that the seeds of greater size and greater weight present the highest quality in attributes for germination and vigour, therefore, full, healthy and mature seeds are stored better than those that do not reach maturity (Doria, 2010).

The storage of nutrients in the cotyledons has a direct influence on the initial growth of the seedlings (Soriano et al., 2011; Bewley et al., 2013; Soriano et al., 2013) and in the dry tropical forest It has been observed that the species that produce larger seeds produce larger seedlings (Soriano et al., 2011), survival in the field (Khurana and Singh, 2004) and in general, an increase in the content of aerial and root biomass (Velázquez- Rosas et al., 2017).

The establishment and survival of the seedlings depends greatly on the content of reserves stored in the seeds (weight), in such a way that seeds with a lower weight express a low level of vigour and, consequently, a decrease in the probability of their establishment (Rubio et al., 2011). However, those seeds of greater weight are also more susceptible to consumption by local fauna with respect to those of lower weight, although the potential for dispersal (zoocoria) may be greater in the former (Fenner and Thompson, 2005).

\section{Number and colour of seeds per tree}

All the trees presented seeds of two colours (light and dark brown), some in the same pod. In trees number 1, 2, 6 and 12, dark brown seeds dominated and in trees 4 and 5, the proportion of the two seed colours was similar (Figure 3). 


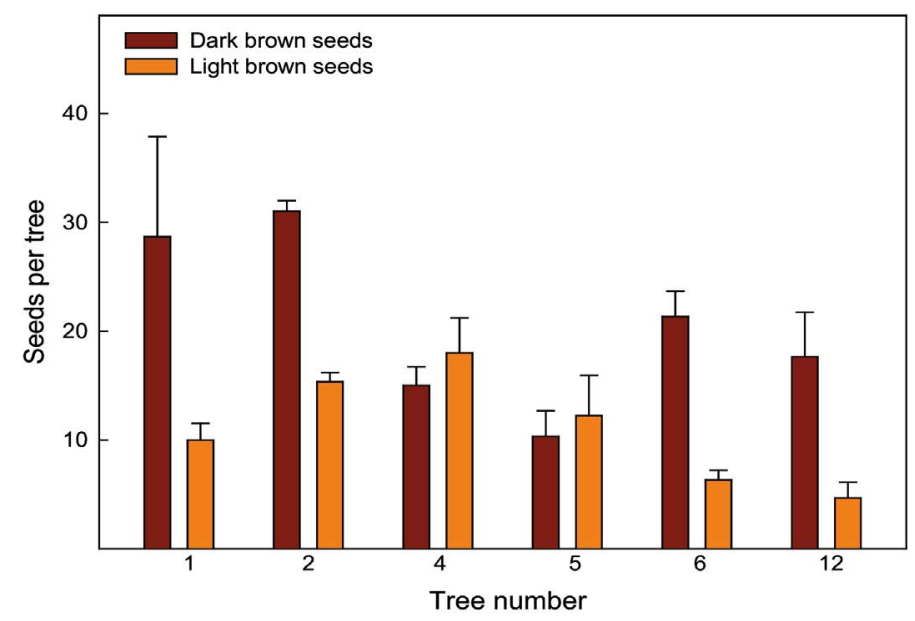

Figure 3. Number and colour of seeds per tree of D. granadillo collected in the Soconusco, Chiapas, Mexico.

In this regard, Doria (2010) refers to the importance of seed colour for germination, highlighting that the difference can be an adaptive characteristic for the species as it can germinate in a wider range of environmental conditions.

In the present case, the dark and light brown colours presented a contrasting difference in germination. Authors such as Debeajun et al. (2000) mention that the colour of the seed is positively correlated with restriction to germination, due to the phenolic components in the seed coat.

Todd and Vadkin (1996) mention that the seeds with darker colours germinate little due to the pigments of the Testa, while the seeds with lighter colours, in addition to having less pigments, absorb less heat, they can be kept at a temperature closer to optimal and germinate in greater quantity.

In addition, dark brown seeds are more prone to phytosanitary problems. They are attacked by insects of the Bruchidae family, and Ctenocolum salvini that deposit their larvae in the young fruits to complete their development and destroy the interior of the seed. Fungi such as Alternaria sp. and Aspergillus sp. have been reported in the seed of Dalbergia retusa Hemsl which is possibly the same that happens with Dalberia granadillo Pittier (CATIE, 2000; Cordero \& Boshier, 2003).

According to Baskin and Baskin, (2001) the variation of sizes in seeds, colours and shapes is controlled by the environment, genetics and their interaction. Among the environmental factors, nutrients, light, shade, time of year, defoliation, temperature and humidity intervene, as well as the position in the fruit. Such variation is related to differences in the requirements for germination and the breaking of dormancy.

\section{Germination}

The highest germination (90 and 96\%) was observed in the light brown seeds in trees number 2 and 12 (Figure 4). However, in the rest of the trees the same trend was presented, that is, greater germination in the light brown seeds. The dark brown seeds, which were the dominant ones in the seed population, presented the lowest germination percentage. 


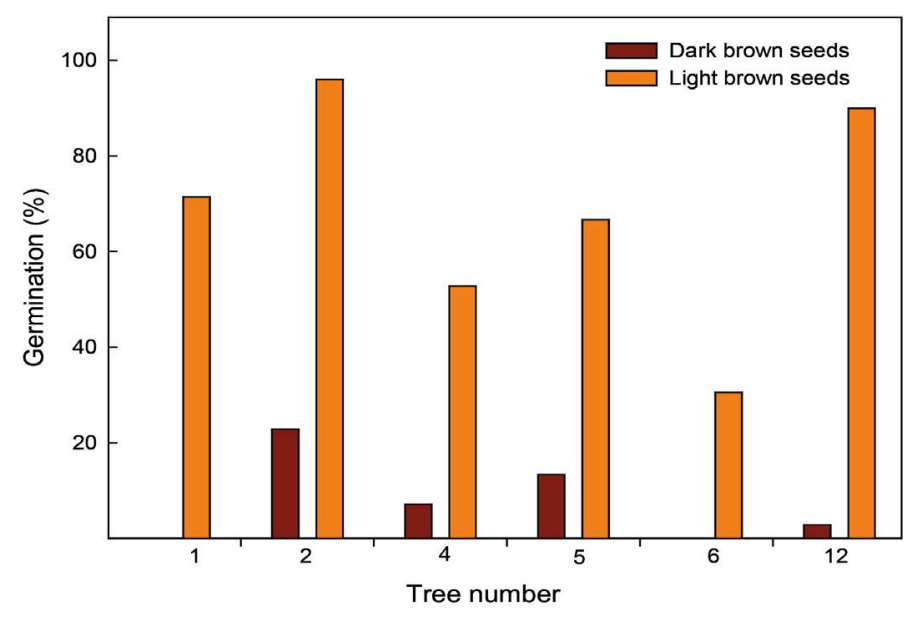

Figure 4. Seed germination by colour of the testa of Dalbergia granadillo Pittier collected in the Soconusco Chiapas, Mexico.

The variation in the colour of the seed may be due to the content and distribution of pigments such as anthocyanins, which are present in some Fabaceae seeds as well as glycosides, flavonoids and condensed tannins (Lobova et al., 2003). This is what can happen with $D$. granadillo Pittier with regarding the amount and distribution of flavonoids that can affect the colour of the cover, as it happens with other tropical species.

In the case of the Dalbergia genus, in D. retusa Hemsl. the seeds present high germination percentage (80-90\%), and when extracting the seeds from the pod, Knoblauch (2001) cites a 2.14-fold increase in germination, improving the viability value.

In other species such as $C$. odorata L. without separating seeds by Testa colour, high germination values similar to those found in this study have been recorded (Arce-Córdova et al., 2018). However, in Mahogany (Swietenia macrophylla King), red cedar (Cedrela odorata L.) and oak or maculís (Tabebuia rosea Bertol) contrasting germination percentages of $76 \%$, $54 \%$ and $37 \%$ respectively are cited (Quinto et al., 2008).

While D. congestiflora Pittier, P. acatlense Benth and M. benthamii J.F. Macbr. which are species of the same family (Fabaceae), showed germination percentages similar to $D$. granadillo Pittier with 90\% germination (González et al., 2019). Other authors such as Rojas and Torres (2014) point out the importance of moderate irrigation in greenhouse conditions in C. odorata L. plantations for seed production, which under these conditions can achieve up to $80 \%$ germination when applying irrigation.

\section{CONGLUSIONS}

There are variations in number of pods, seeds per pod, seed size and weight of 100 seeds among the $D$. granadillo Pittier tree population. Pods with a dark brown seed predominate in all trees. The germination of the seeds was differential to the colour of the Testa. The highest percentage was registered in light brown seeds and they represent the smallest number of the total (96\%). 


\section{REFERENCES}

Agustín-Sandoval W.G., Espinosa-Zaragoza S., Avendaño-Arrazate C.H., Reyes-Reyes A. L., RamírezGonzález S.I., López-Báez O., Andrade-Rodríguez M., Rangel-Zaragoza J.L. (2017). Calidad de semillas de primavera (Roseodendron donnell-smithii Miranda syn Tabebuia donnell-smithii Rose). Agroproductividad, 10 (3): 81- 86. Recuperado a partir de https://www.revista-agroproductividad.org/ index.php/agroproductividad/article/view/974

Alderete-Chávez, Ángel; de la Cruz Landero, Nancy; González de la Torre, Juan Elio (2005). Variación en semillas de Cedrela odorata L. procedentes de los estados de Campeche y Tabasco, México. Foresta Veracruzana, 7 (2): 41-44. https://www.redalyc.org/pdf/497/49770207.pdf

Arce-Córdova, D. Espinosa-Zaragoza, S., Aguirre-Medina, J.F., Wong-Villarreal, A., Avendaño-Arrazate, C.H., Cadena-Iñiguez, J. (2018). Características morfométricas y germinación de semillas de Cedrela odorata L. Agroproductividad, 11 (3): 82- 89. Recuperado a partir de https://revista-agroproductividad. org/index.php/agroproductividad/article/view/221

Baskin, C. C., and J. M. Baskin. (2001). Seeds. Ecology, Biogeography and Evolution of Dormancy and Germination. Academic Press. San Diego. 666 p.

Bewley, J. D., Bradford, K., Hilhorst, M. and Nonogaki, H. (2013). Seeds Physiology of Development, Germination and Dormancy. 3rd. ed. Springer. New York, USA. 445 p.

CATIE. (Centro Agronómico Tropical de Investigación y Enseñanza). (2000). Manejo de semillas de 100 especies forestales de América Latina. Turrialba, Costa Rica. 204 pág.,

Cervantes M. A. (2016). La conservación del granadillo en México: una carrera contra el tiempo. CONABIO. Biodiversitas. 128:6-11

CITES. (Convención sobre el comercio internacional de especies amenazadas de fauna y flora silvestres) (2013). CoP16 Prop. 61. Dalbergia retusa y Dalbergia granadillo, Inclusion in Appendix II. Belize. Disponible en: https://cites.org/sites/default/files/esp/cop/16/prop/S-CoP16-Prop-61.pdf

CITES. (Convención sobre el comercio internacional de especies amenazadas de fauna y flora silvestres). (2015). PC22 Doc. 22.4: Evaluación del riesgo de las especies maderables del género Dalbergia en México", Secretaría de la CITES, Ginebra.

CITES. (Convención sobre el comercio internacional de especies amenazadas de fauna y flora silvestres). (2016a). Guía de identificación de las maderas tropicales protegidas por la Convención sobre el Comercio International de Especies Amenazadas de Fauna y Flora Silvestres (en línea). Disponible en: file:///E:/ DALBERGIA/ART.\%20AGROPRODUCTIVIDAD/INFORME\%20T\%C3\%89CNICO\%20 DEL\%20PROYECTO\%20LABORATORIO\%20FORENSE\%20IDENTIFICACI\%C3\%93N\%20 MADERAS.pdf

CITES. (Convención sobre el comercio internacional de especies amenazadas de fauna y flora silvestres). (2016b). Informe técnico del proyecto laboratorio forense identificación maderas por la Convención sobre el Comercio International de Especies Amenazadas de Fauna y Flora Silvestres (en línea). Disponible en: http:/www.itto.int/files/user/cites/guatemala/INFORME\%20T\%C3\%89CNICO\%20 DEL\%20PROYECTO\%20LABORATORIO\%20FORENSE\%20IDENTIFICACI\%C3\%93N\%20 MADERAS.pdf

Colín-Urieta, S., Carrillo-Parra, A., Rutiaga-Quiñones, J.G., López-Albarran, P., Gabriel-Parra, R. y CorralRivas, J.J. (2019). Assessing the natural durability of different tropical timbers in soil-bed tests. Maderas, Ciencia y tecnología 21(2): 231 - 238. https://www.redalyc.org/jatsRepo/485/48559145006/html/index. html

CONABIO. (Comisión Nacional para el Conocimiento y Uso de la Biodiversidad). (2017). Granadillo (Dalbergia granadillo), Enciclovida, Biodiversidad Mexicana, Comisión Nacional para el Conocimiento y Uso de la Biodiversidad, México, Disponible en: https://enciclovida.mx/especies/186583-dalbergiagranadillo

Cordero, J. and Boshier, D. (eds.) (2003). Árboles de Centroamérica: Un manual para extensionistas. Turrialba, CR, OFI/CATIE. 1079 p.

Debeajun, I., L. Kloosterziel M., and M. Koorneef. (2000). Influence of the testa on seed dormancy, germination, and longevity in Arabidopsis. Plant Physiology 122(2) 403-414. doi: 10.1104/pp.122.2.403.

Díaz-Gallegos, J. R., J. F. Mas \& A. Velázquez. (2010). Trends of tropical deforestation in Southeast Mexico. Singapore Journal of Tropical Geography 31(2):180-196. DOI: 10.1111/j.1467-9493.2010.00396.x

Doria J. (2010). Generalidades sobre las semillas: su producción, conservación y almacenamiento. Cultivos Tropicales, 37(1): 74-85 Disponible en: http://scielo.sld.cu/pdf/ctr/v31n1/ctr11110.pdf

FAO. (Organización de las Naciones Unidas para Alimentación y la Agricultura). (2008). Base referencial mundial del recurso suelo e Informes sobre recursos mundiales de suelos. Roma Italia 103p.

Fenner, M., and Thompson, K. (2005). The Ecology of Seed. Cambridge University Press. New York. 249 p. 
González Vélez G., Agustina R. Andrés-Hernández, Valdez-Eleuterio G, Álvarez-Quiroz N., MartínezMoreno D., Sombra P. Rivas-Arancibia. (2019). Germinación de semillas de seis especies arbóreas maderables de una selva baja caducifolia en Puebla, México. Revista Agrociencia 54: 227-240. Disponible en: file://E:/DALBERGIA/Germinacion\%20de\%20seis\%20especies.pdf

Guala G, Döring M (2020). Dalbergia granadillo Pittier Integrated Taxonomic Information System (ITIS). National Museum of Natural History, Smithsonian Institution. Checklist dataset https://doi. org/10.15468/rjarmt accessed via GBIF.org on 2021-06-27.

Guridi, G. L. I. y García-López, Y. A. (1996). Las maderas en los instrumentos musicales de cuerda de Paracho, Michoacán, México. Morelia: Editorial Universitaria, Universidad Michoacana de San Nicolás de Hidalgo. Facultad de Ingeniera en Tecnología de la Madera. 45p

Herrera-Castro, M., Quintanar-Isaías, A., Orduña-Bustamante, F., Olmedo-Vera; B. y Jaramillo-Pérez, A.T. (2019). Identificación de la madera y análisis acústico de tres teponaztlis, instrumentos musicales aztecas originales. Madera y Bosques 25(1): 1-17. doi: 10.21829/myb.2019.2511690

INEGI. (Instituto Nacional de Estadística, Geografía e Informática). (2017). Anuario estadístico y geográfico de Chiapas. https://www.datatur.sectur.gob.mx

ISTA. (International Seed Testing Association). 2010. Reglas del ISTA. Septiembre de 2010. Publicado en línea en: http://www.analisisdesemillas.com.ar/index.php?option=com_content\&task=view\&id=15\&It emid $=31$

Knoblauch, B. (2001). Estudio ecológico, silvícola y de utilización del Granadillo (Dalbergia tucurensis J.D. Smith) en bosques latifoliados de Honduras. Proyecto especial presentado como requisito parcial para optar al título de Ingeniero Agrónomo en el Grado Académico de Licenciatura, Carrera de Desarrollo Socio-económico y Ambiente, El Zamorano, Honduras. 44 p.

Khurana, E., and Singh, J. S. (2004). Germination and seedling growth of five tree species from tropical dry forest in relation to water stress: impact of seed size. Journal of Tropical Ecology 20(04):385-396. Doi: 10.1017/S026646740400135X

Lobova, A., L. Mori A., S. F. Blanchard, H. Peckham, and C. Dominique P. (2003). Cercopia as food resource for bats in French Guiana and the significance of fruits structure in seed dispersal and longevity. American Journal of Botany 90(3): 388-403. doi: 10.3732/ajb.90.3.388.

Luna, G., Rodríguez, O., Enríquez, V., Ruíz, L., García, A. y Campos, A. (2018). Frutos y semillas de Bursera simplex Rzed. \& Calderon en diferentes sitios y estructura arbórea. Revista Mexicana de Ciencias Forestales, 9 (48): 92-114. https://cienciasforestales.inifap.gob.mx/index.php/forestales/article/view/188

Mendizábal-Hernández, L. Del C., J.J. Hernández-Viveros, J. Alba-Landa, E. Ramírez-García, y H. CruzJiménez. (2012). Potencial y eficiencia de producción de semillas de Cedrela odorata L. Foresta Veracruzana 14(2):31-36. https://www.redalyc.org/pdf/497/49728290005.pdf

Mendizábal-Hernández, L. Del C., J.J. Hernández-Viveros, y J. Alba-Landa. (2013). Estudio de conos y semillas de Cedrela odorata L. en una generación parental y una generación filial. Foresta Veracruzana 15(1):45-51. https://www.redalyc.org/pdf/497/49728291006.pdf

Niembro, A. (1990). Semillas de árboles y arbustos: Ontogenia y estructura. Editorial Limusa, Mexico. 285p:

Pittier, H. (1922). On the species of Dalbergia of México and Central América. Journal of the Washington Academy of Sciences, 12 (3 February): 54-64. Retrieved from: Stable URL: https://www.jstor.org/stable/24532566

Quinto, L., Martínez-Hernández P. A., Pimentel-Bribiesca L., Rodríguez-Trejo D. A. (2008). Alternativas para mejorar la germinación de semillas de tres árboles tropicales. Revista Chapingo Serie Ciencias Forestales y del Ambiente 15(1): 23-28. https://www.redalyc.org/pdf/629/62916073003.pdf

Rojas, R. y Torres, C. (2014). Árboles del Valle Central de Costa Rica: reproducción cedro amargo (Cedrela odorata L.). Revista Forestal Mesoamericana 11(26): 25-27. file://C:/Users/JF\%20Aguirre\%20Medina/ Downloads/Dialnet-ArbolesDelValleCentralDeCostaRica-5123216.pdf

Rubio, L., Romero, R., Rojas, Z., Durán, D. y Gutierrez, G. (2011). Variación del tamaño de frutos y semillas en siete especies de encino (Quercus, Fagaceae). Polibotánica 32: 135-151. http://www.scielo.org.mx/ scielo.php?script=sci_arttext\&pid=S1405-27682011000200008

Sánchez, S., Jurado, Y., Pando, M., Flores, R. y Muro, P. (2010). Estrategias germinativas de las semillas en ambientes áridos. Revista Chapingo Serie Zonas Áridas. 9 (1): 35-38. https://www.redalyc.org/ pdf/4555/455545062006.pdf

SEMARNAT (Secretaría del Medio Ambiente y Recursos Naturales). (2002). Norma Oficial Mexicana NOM-059-SEMARNAT-2001, Protección Ambiental Especies Nativas de México de Flora y Fauna Silvestres-Categorías de riesgo y especificaciones para su inclusión, exclusión o cambio, lista de especies en riesgo. Diario Oficial de la Federación, México, D.F., México.

Seltmann, P., Leyer, I., Renison, D. \& Hensen, I. (2007). Variation of seed mass and its effects on germination in Polylepis australis: implications for seed collection. New Forests 33(2): 171-181. DOI: 10.1007/s1 1056-0069021-8 
Soriano D., Orozco-Segovia, A., Márquez-Guzmán, J., Kitajima, K., Gamboa-de Buen, A. and Huante, P. (2011). Seed reserve composition in 19 tree species of a tropical deciduous forest in Mexico and its relationship to seed germination and seedling growth. Annals of Botany 107, (6): 939-951. Doi: $10.1093 /$ aob/mcr041

Soriano, D., Huante, P., Buen, A., \& Orozco-Segovia, A. (2013). Seed reserve translocation and early seedling growth of eight tree species in a tropical deciduous forest in Mexico. Plant Ecology, 214(11), 1361-1375. Retrieved July 5, 2021, from http://www.jstor.org/stable/24553704

Suárez-Islas A., Capulín-Grande J., Mateo-Sánchez J. J. (2020). Performance of Dalbergia palo-escrito Rzed. \& Guridi-Gómez, a valuable timber tree, in a coffee plantation in Hidalgo, Mexico. Bois et Forêts des Tropiques, 344: 47-57. Doi: https://doi.org/10.19182/bft2020.344.a31899

Todd, J., and L. O. Vadkin. (1996). Duplications that suppress and deletions that restore expression from a Chalcone syntrase multigene family. Plant Cell. 8(4): 687-699. doi: 10.1105/tpc.8.4.687.

Velázquez-Rosas, N., Ruiz-Guerra, B., Sánchez-Coronado, M. E., Gamboa-de Buen, A. and Orozco-Segovia, A. (2017). Morphological variation in fruits and seeds of Ceiba aesculifolia and its relationship with germination and seedling biomass. Botanical Sciences, 95: 81-91. Doi: 10.17129/botsci.636 